\title{
Innominate vein turn-down procedure: Killing two birds with one stone
}

\author{
Viktor Hraska, MD, PhD, ${ }^{\text {a,b }}$ Vibeke E. Hjortdal, $\mathrm{MD}, \mathrm{PhD},{ }^{\mathrm{c}}$ Yoav Dori, $\mathrm{MD}, \mathrm{PhD},{ }^{\mathrm{d}}$ and Christian Kreutzer, $\mathrm{MD}^{\mathrm{e}}$
}

Feature Editor Note-In an effort to design a perfect thirdstage palliation for our single-ventricle patients, our specialty has been making tremendous efforts to compensate for the well-known disadvantages of a circulatory setting involving a lifelong state of high systemic venous pressure. While we aim to excel at each stage of single-ventricle palliation to prevent a suboptimal Fontan circulation, our focus has indeed sharpened to also understand the variations and impact of the lymphatic system on the outcome of patients before or following third-stage palliation. Novel diagnostic techniques using magnetic resonance imaging aid in visualizing the problems in lymphatic drainage in a standardized manner, whereas novel targeted interventional and surgical techniques by experienced teams offer invaluable solutions for one of the conundrums of the Fontan circulation.

Dr Hraśka and expert colleagues graciously contribute to this issue of the Journal with a multidisciplinary invited expert review of their current surgical and interventional strategies to address lymphatic system disturbances in Fontan circulation. The article overviews a clear diagnostic classification of lymphatic pathologies, leading to a decision-making tree. Medical, interventional, and surgical options are discussed in detail. The authors offer an updated cohort with characteristics and outcome of patients who were treated with the innovative innominate vein turn-down procedure. This excellent contribution is accompanied by images and illustrations. The congenital editors thank the authors for this invaluable presentation of their experience.

\section{Can Yerebakan, MD}

While systemic venous hypertension is the most prominent hemodynamic disturbance in the Fontan circulation, recent work has identified the consequent lymphatic

\footnotetext{
From the a Division of Pediatric Cardiothoracic Surgery, Herma Heart Institute, Children's Wisconsin; and 'Department of Surgery, Medical College of Wisconsin, Milwaukee, Wis; 'Department of Cardiothoracic Surgery; Rigshospitalet, Copenhagen, Denmark; ${ }^{\mathrm{d}}$ Jill and Mark Fishman Center for Lymphatic Disorders and Lymphatic Research, Children's Hospital of Philadelphia, Philadelphia, Pa; and ${ }^{\mathrm{e}}$ Division of Pediatric Cardiovascular Surgery. Hospital Universitario Austral. Universidad Austral. Pilar, Buenos Aires, Argentina.

Received for publication Jan 18, 2021; accepted for publication Jan 19, 2021; available ahead of print March 18, 2021.

Address for reprints: Viktor Hraska, MD, PhD, Division of Pediatric Cardiothoracic Surgery, Herma Heart Institute, Children's Wisconsin, 9000 W. Wisconsin Ave, B730, Milwaukee, WI 53226 (E-mail: vhraska@ chw.org).

JTCVS Techniques 2021;7:253-60

2666-2507

Copyright (C) 2021 The Author(s). Published by Elsevier Inc. on behalf of The American Association for Thoracic Surgery. This is an open access article under the CC BY-NC-ND license (http://creativecommons.org/licenses/by-nc-nd/4.0/).

https://doi.org/10.1016/j.xjtc.2021.01.045
}

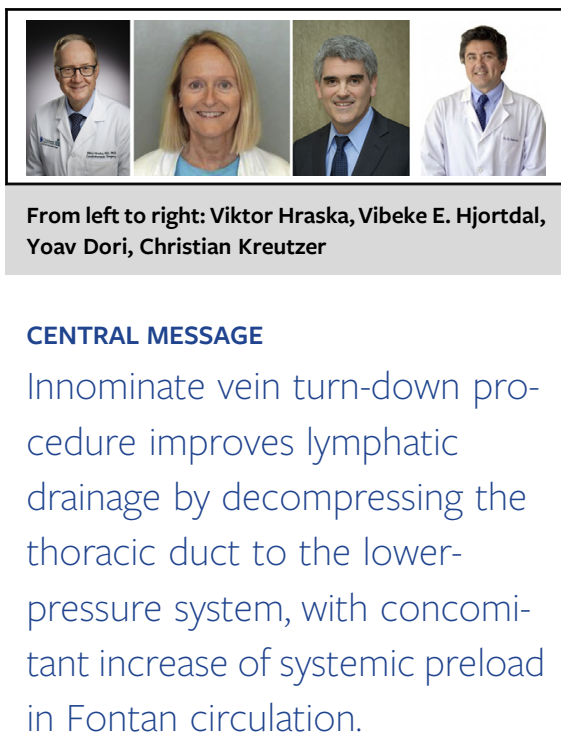

See Commentaries on pages 261 and 263 .

hypertension and impaired drainage as pathophysiologic in the development of pleural effusions, edema, ascites, plastic bronchitis (PB), and protein-losing enteropathy (PLE) ${ }^{1-4}$ Novel interventional and surgical approaches have been developed to treat post-Fontan lymphatic complications with promising outcomes. ${ }^{2-9}$

\section{LYMPHATIC PATHOLOGY}

Under normal physiological conditions, an estimated 2 to $3 \mathrm{~L}$ of protein-rich fluid are filtered out from the blood circulation and into the interstitial space and returned to the blood circulation by the lymphatic vessels. The lymphatic vasculature is a ubiquitous bodily net functioning as a unidirectional drainage and transport system that is responsible for returning all interstitial fluid back to the blood circulation. The lymphatic vessels contract to propel the fluid forward, with contractile properties comparable with those of heart ventricles. Similar to the heart and intestines, pacemaker cells have been proposed to uphold frequency and secure continuous movement through the system, ${ }^{10}$ with ion channels required for depolarization. ${ }^{11}$ In addition, both increased tension in the vessel wall and adrenergic innervation have been shown to increase contraction frequency, enabling an estimated 10-fold increase in fluid removal if needed.

The thoracic duct (TD) has a critical role in lymphatic transport-draining approximately $85 \%$ of lymph production from the entire body except for the right hemithorax, 
right head and neck, and right arm. The majority of TD flow comes from the liver and intestine, and in the majority of cases the TD drains at the posterior aspect of the left internal jugular and subclavian vein confluence and, when present, the right TD drains at the right subclavian jugular vein confluence. A valve prior to its drainage prevents blood flow into the TD. There are 2 distinct pressure elements that substantially determine the TD pressure - a forward pressure from lymph formation and a backpressure from the venous pressure at the lymph drainage point., ${ }^{2,12}$

In the failing Fontan circulation, the central venous pressure (CVP) often exceeds 18 to $20 \mathrm{~mm} \mathrm{Hg}$. There is experimental evidence that such elevation of CVP leads to a significant increase of lymphatic production in the hepatosplanchnic region, resulting in greater pressure and flow in the TD. At the same time, the transport capacity of the TD is limited by increasing outflow pressure (backpressure exerted by elevated CVP), demonstrated by a clear breakpoint in the lymph flow-outflow pressure curve. At outflow pressures above the breakpoint, lymph flow decreases linearly with outflow pressure and ceases at an outflow pressure of $24 \mathrm{~mm} \mathrm{Hg} .{ }^{2,13}$ In the Fontan circulation, the transport capacity of the TD is further limited by dilatation of the TD, resulting in incompetence of the lymphatic valves and stasis, and by lack of "diastolic suctioning" of lymph. In addition, lymphovenous communications, either to systemic or pulmonary veins, are not open and thus cannot decompress the lymphatic system. ${ }^{3}$ An altered lymphatic architecture with vessels adjacent to a lower pressure lumen may lead to symptomatic lymphatic failure. In patients with PLE, lymphatic congestion and flow obstruction result in decompression of the lymphatic system through a route of lower resistance in the duodenal wall, with protein-rich lymphatic fluid spilling out into the low-pressure environment of the intestines. ${ }^{14,15}$ In the lungs, increased afterload resistance and increased lymphatic production may cause lymphatic breakthrough to the pulmonary airways, causing the devastating condition PB.

\section{PREOPERATIVE EVALUATION AND DECISION- MAKING}

The long-term effect of the lymphatic congestion on the contractional capacity is due to functional impairment with losing the ability to generate a greater pressure and increase contraction frequency. The contraction frequency and strength of the peripheral lymphatic system can be measured with near-infrared fluorescent imaging. ${ }^{11,16}$

Magnetic resonance imaging (MRI) is the imaging modality of choice for screening patients with thoracic lymphatic disorders and for imaging lymphatic anatomy and flow in patients with lymphatic failure. ${ }^{5,14,15,17}$ MRI has been applied to visualize the central lymphatic architecture using heavily $\mathrm{T} 2$-weighted images in patients with single-ventricle physiology. T2 MRI has also been shown to correlate with acute Fontan outcomes and should be used as a screening tool in all patients undergoing single-
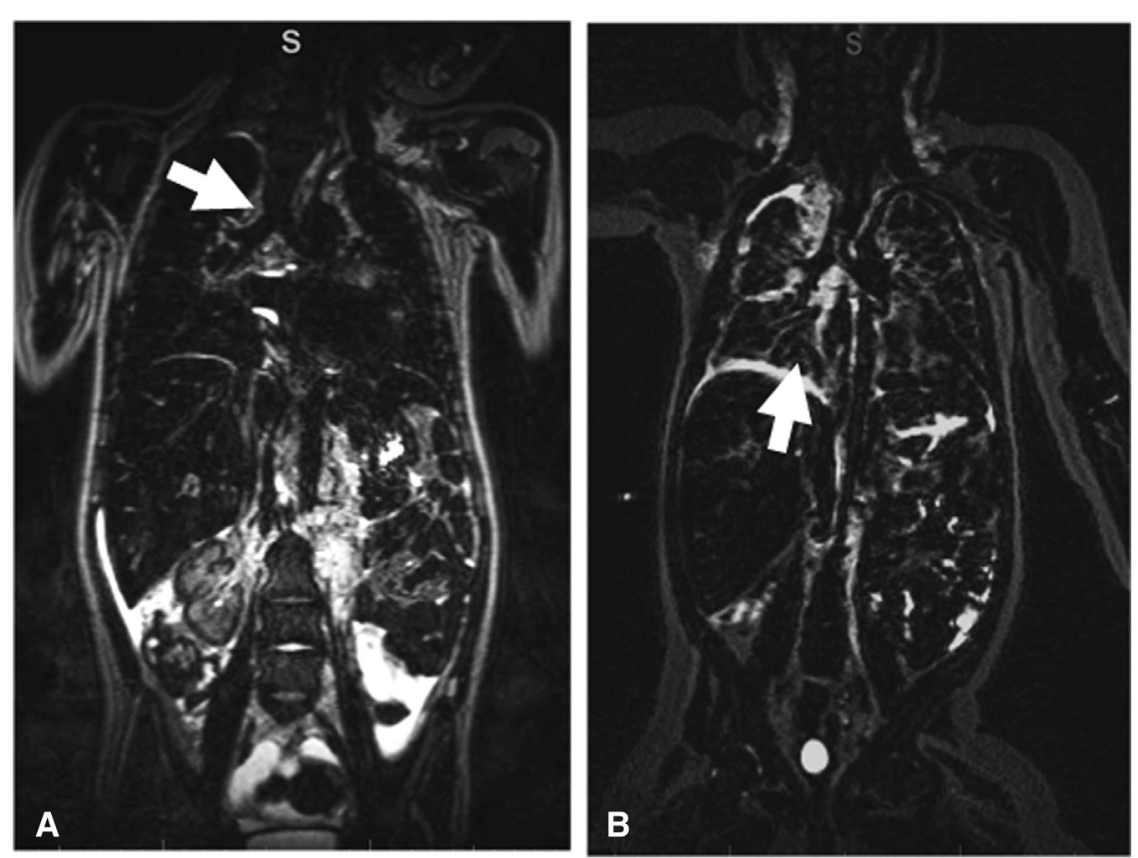

FIGURE 1. A, Coronal MIP of a T2 image showing a patient with type 3 thoracic lymphatic abnormality with high T2 signal extending into the mediastinum (arrow). B, Coronal MIP of T2 image showing patient with type 3 thoracic lymphatic abnormality with high T2 signal extending into the lung parenchyma (arrow). MIP, Magnetic imaging picture. 

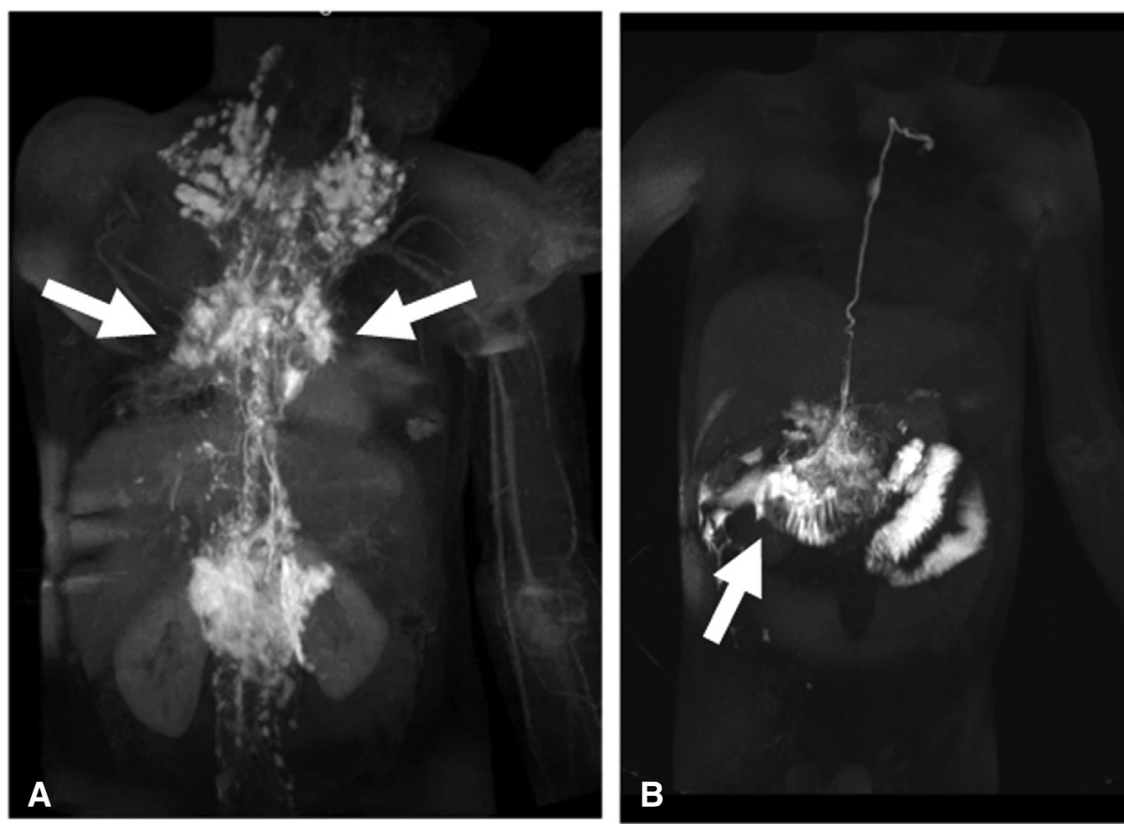

FIGURE 2. A, Coronal MIP image of intranodal DCMRL in a patient with PB showing bilateral pulmonary perfusion (arrows). B, Coronal MIP image of intrahepatic DCMRL in a patient with PLE showing a duodenal leak (arrow). MIP, Magnetic imaging picture; $D C M R L$, dynamic contrast magnetic resonance lymphangiography; $P B$, plastic bronchitis; $P L E$, protein-losing enteropathy.

ventricle palliation before undergoing the Fontan operation (Figure 1). ${ }^{14}$ A new classification of lymphatic thoracic abnormalities has been introduced using a scale of 1 to 4 according to progression of severity (type 1: little or no abnormalities; type 2: abnormalities in the supraclavicular region; type 3: abnormalities in the mediastinum; type 4 : abnormalities extending in to the mediastinum and the lungs). For patients with thoracic lymphatic disorders such as chylothorax or PB, intranodal and preferably also intrahepatic dynamic-contrast magnetic resonance lymphangiography (DCMRL) should be performed for interventional planning and to determine whether the patient has duodenal involvement, which could indicate risk for PLE (Figure 2) ${ }^{15}$ In addition, TD outlet patency should be confirmed. This can be done using contrast ultrasound lymphangiography or direct lymphangiography. ${ }^{16}$ For patients with abdominal lymphatic abnormalities, such as PLE or ascites, intrahepatic and intramesenteric DCMRL are the imaging modality of choice for understanding the etiology and for interventional planning (Figure 2). ${ }^{15,17}$

\section{MEDICAL MANAGEMENT}

The contractile properties, comparable with those of the heart, hold promise for the development of pharmacologic ways to optimize the lymphatic function. Norepinephrine increases the frequency of contractions as well as pressures generated in isolated human lymphatic vessels, and dopamine infusion has been reported to reduce symptoms in a small series of patients. ${ }^{18}$

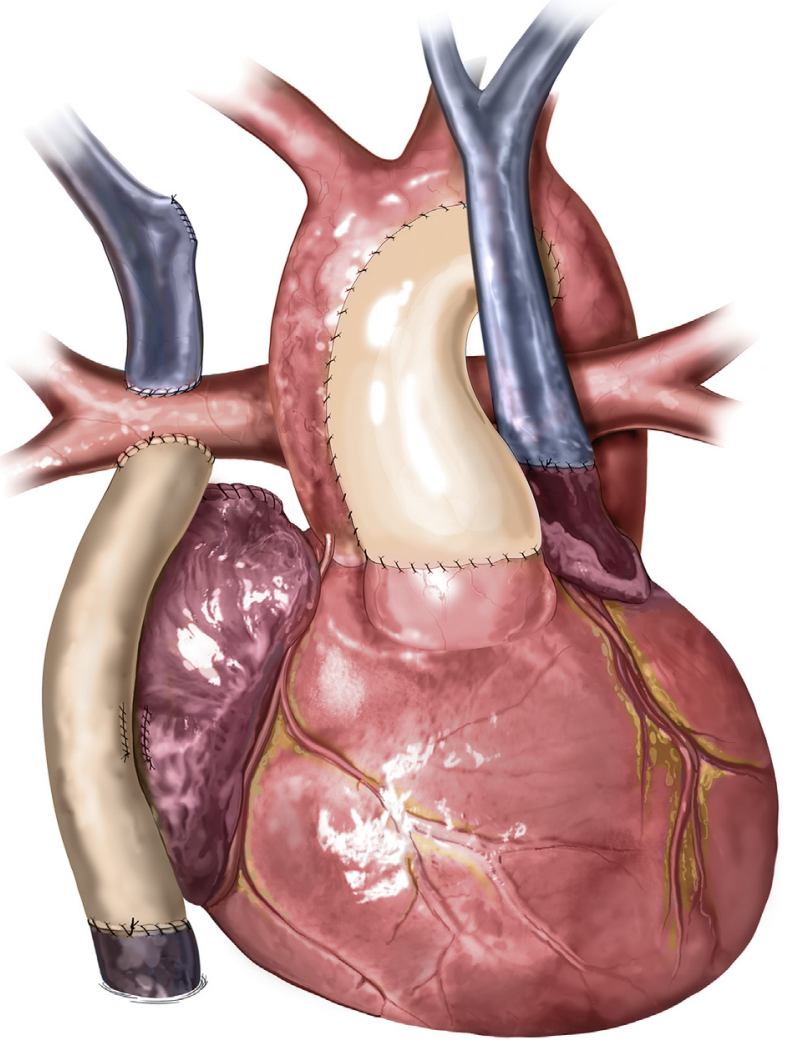

FIGURE 3. The innominate vein is directly anastomosed with left atrial appendage. ${ }^{2}$ (Reprinted with permission from Seminars in Thoracic and Cardiovascular Surgery: Pediatric Cardiac Surgery Annual). 


\section{INTERVENTIONAL MANAGEMENT}

In all patients with a lymphatic dysfunction, cardiac evaluation, including cardiac catheterization, should be performed to determine whether there are reversible cardiac causes that could be treated, such as pulmonary artery stenosis or superior vena cava obstruction. Medical and conservative treatments should also be optimized.

Lymphatic interventions can be divided into those meant to decompress the lymphatic system, such as lymphovenous anastomosis and percutaneous or surgical innominate vein $(\mathrm{InV})$ turn-down, and those that are meant to reroute lymphatic flow away from abnormal lymphatic networks, such as selective lymphatic duct embolization (SLDE) or TD embolization. The decision on the therapeutic approach depends on the underlying disease and lymphatic anatomy. SLDE is the preferred interventional approach, as it maintains TD patency and flow, preserving the option of TD-decompression procedures. This is especially important in patients with multicompartment lymphatic failure or those with thoracic abnormalities and concerning findings on intrahepatic DCMRL, such as duodenal perfusion or leak. Complete TD embolization should be reserved for cases in which the TD outlet is occluded and lymphovenous anastomosis is not an option, there are multiple decompressing vessels connecting to the TD (making SLDE impossible), the TD is not fully formed, or when the patient is unstable and emergent closure of TD flow is needed.

\section{SURGICAL MANAGEMENT}

The TD, which in the majority of patients enters the circulation at the left subclavian-jugular vein junction, is decompressed by turning down the InV directly to the common atrium. ${ }^{7}$ The procedure is technically simple and safe. The principles have been published elsewhere ${ }^{2,7}$ and include the following steps: (1) the procedure is performed as a part of Fontan operation on cardiopulmonary bypass; (2) the InV is mobilized up to the left venous angle; (3) one should avoid dissection of the posterior aspect of the subclavian-jugular confluence and disruption of the TD and lymphatic collaterals; (4) all accessible venous branches of the jugular and subclavian vein are clipped; (5) mobilization of the atrial mass to the extent possible and determine the optimal course for the turn-down dictated by the size of the ascending aorta, morphology of the atrial mass, and tenacity of adhesions around central structures; (6) clamp the $\mathrm{InV}$ at the junction with the right internal jugular vein

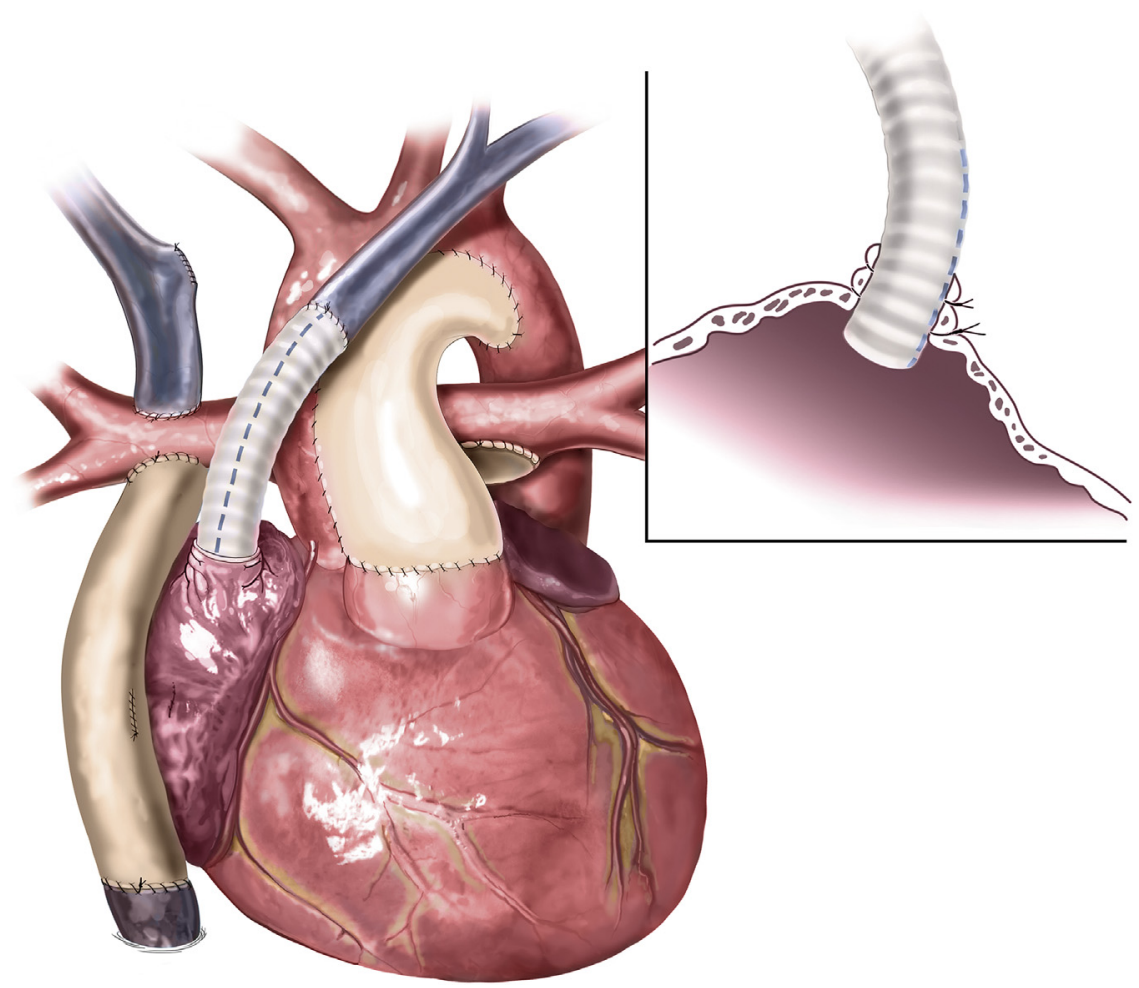

FIGURE 4. The innominate vein is anastomosed with right atrium using an interposition graft and the dunk technique (inset). ${ }^{2}$ (Reprinted with permission from Seminars in Thoracic and Cardiovascular Surgery: Pediatric Cardiac Surgery Annual). 
TABLE 1. Demographic and clinical variables of patients who received an InV turn-down procedure

\begin{tabular}{|c|c|c|c|c|c|c|c|c|c|}
\hline $\begin{array}{c}\text { Patient } \\
\text { no. }\end{array}$ & $\begin{array}{c}\text { Age, } \\
\mathbf{y}\end{array}$ & Diagnosis & $\begin{array}{l}\text { Last surgical } \\
\text { palliation }\end{array}$ & PLE/PB & Ascites & Effusions & Procedure & $\begin{array}{l}\text { Follow- } \\
\text { up, mo }\end{array}$ & Outcome \\
\hline 1 & 5 & $\begin{array}{l}\text { SV, Heterotaxy } \\
\text { syndrome, } \\
\text { Asplenia, } \\
\text { u-CAVC }\end{array}$ & $\begin{array}{l}\text { EC-Fontan } \\
\text { AV valve repair }\end{array}$ & $\mathrm{Y} / \mathrm{N}$ & $\begin{array}{l}\text { Yes, } \\
\text { massive }\end{array}$ & $\begin{array}{l}\text { Yes, } \\
\text { bilateral }\end{array}$ & $\begin{array}{l}\text { R Glenn } \\
\text { take-down, } \\
\text { AVVR, and } \\
\text { InV turn-down }\end{array}$ & 3 & $\begin{array}{l}\text { Late death, pulmonary } \\
\text { hemorrhage }\end{array}$ \\
\hline 2 & 19 & $\begin{array}{l}\text { SV, Heterotaxy } \\
\text { syndrome, } \\
\text { Asplenia, } \\
\text { u-CAVC }\end{array}$ & EC-Fontan & $\mathrm{Y} / \mathrm{N}$ & Yes & Yes & $\begin{array}{l}\text { InV turn-down } \\
\text { (RJSC-RA) }\end{array}$ & 36 & $\begin{array}{l}\text { Alive, doing well, normal } \\
\text { albumin }\end{array}$ \\
\hline 3 & 53 & $\begin{array}{l}\text { Tricuspid } \\
\text { atresia II }\end{array}$ & $\begin{array}{l}\text { Atrio-pulmonary } \\
\text { Fontan }\end{array}$ & $\mathrm{Y} / \mathrm{N}$ & $\begin{array}{l}\text { Yes, } \\
\text { massive }\end{array}$ & No & $\begin{array}{l}\text { Fontan } \\
\text { conversion } \\
\text { and InV } \\
\text { turn-down }\end{array}$ & 9 & $\begin{array}{l}\text { Alive, doing well, normal } \\
\text { albumin }\end{array}$ \\
\hline 4 & 6 & PA IVS & EC-Fontan & $\mathrm{N} / \mathrm{Y}$ & No & $\begin{array}{l}\text { Yes, } \\
\text { right }\end{array}$ & $\begin{array}{l}\text { InV } \\
\text { turn-down } \\
\text { and PA plasty }\end{array}$ & 24 & $\begin{array}{l}\text { Alive, doing well, no } \\
\text { PB after intervention }\end{array}$ \\
\hline 5 & 6 & $\begin{array}{l}\text { SV, } \\
\text { Heterotaxy } \\
\text { syndrome, } \\
\text { asplenia, } \\
\text { u-CAVC }\end{array}$ & EC-Fontan & $\mathrm{N} / \mathrm{Y}$ & No & No & InV turn-down & 16 & $\begin{array}{l}\text { Alive, with recurrent of mild PB } \\
\text { at } 13 \text { mo postoperative, since } \\
\text { then doing well }\end{array}$ \\
\hline 6 & 3 & HLHS & EC-Fontan & $\mathrm{N} / \mathrm{N}$ & $\begin{array}{l}\text { Yes, } \\
\text { massive }\end{array}$ & $\begin{array}{l}\text { Yes, } \\
\text { bilateral }\end{array}$ & InV turn-down & 24 & $\begin{array}{l}\text { Late death, ventricular } \\
\text { dysfunction }\end{array}$ \\
\hline 7 & 8 & HLHS & EC-Fontan & $\mathrm{Y} / \mathrm{N}$ & $\begin{array}{l}\text { Yes, } \\
\text { massive }\end{array}$ & $\begin{array}{l}\text { Yes, } \\
\text { bilateral }\end{array}$ & InV turn-down & 0 & $\begin{array}{l}\text { Died during postoperative } \\
\text { recovery from respiratory } \\
\text { arrest due to pulmonary } \\
\text { hemorrhage }\end{array}$ \\
\hline 8 & 6 & HLHS & EC-Fontan & $\mathrm{Y} / \mathrm{Y}$ & No & No & InV turn-down & 27 & $\begin{array}{l}\text { Alive with no further symptoms of } \\
\text { PLE or PB }\end{array}$ \\
\hline 9 & 0.8 & DILV & Glenn & $\mathrm{N} / \mathrm{N}$ & Yes, massive & No & InV turn-down & 21 & $\begin{array}{l}\text { Alive with recurrence of effusion } \\
\text { at } 3 \text { mo postoperatively, } \\
\text { requiring percutaneous catheter } \\
\text { intervention of narrowing at } \\
\text { InV-atrial anastomosis }\end{array}$ \\
\hline 10 & 8 & DILV & EC-Fontan & $\mathrm{N} / \mathrm{Y}$ & No & No & InV turn-down & 20 & $\begin{array}{l}\text { Alive, with recurrent of } \mathrm{PB} \text { at } \\
3 \text { mo postoperative, requiring } \\
\text { percutaneous stenting of InV- } \\
\text { atrial anastomosis. No } \\
\text { recurrence of } \mathrm{PB} \text { since then }\end{array}$ \\
\hline 11 & 3.5 & DILV & EC-Fontan & $\mathrm{N} / \mathrm{N}$ & No & $\begin{array}{l}\text { Yes, } \\
\text { massive }\end{array}$ & InV turn-down & 18 & $\begin{array}{l}\text { Alive, had recurrence of effusion } \\
\text { at } 6 \text { mo postoperatively and } \\
\text { required stenting of narrowing } \\
\text { at InV-atrial anastomosis. No } \\
\text { recurrence of effusion since } \\
\text { then. }\end{array}$ \\
\hline 12 & 10.5 & HLHS & EC-Fontan & $\mathrm{Y} / \mathrm{N}$ & No & No & InV turn-down & 7 & $\begin{array}{l}\text { Had extensive thrombus noted at } \\
\text { time of InV turn-down. Did } \\
\text { have improving PLE but } \\
\text { eventually readmitted and died } \\
\text { from sepsis c/b renal failure }\end{array}$ \\
\hline
\end{tabular}


TABLE 1. Continued

\begin{tabular}{|c|c|c|c|c|c|c|c|c|c|}
\hline $\begin{array}{c}\text { Patient } \\
\text { no. }\end{array}$ & $\begin{array}{c}\text { Age, } \\
\mathbf{y}\end{array}$ & Diagnosis & $\begin{array}{c}\text { Last surgical } \\
\text { palliation }\end{array}$ & PLE/PB & Ascites & Effusions & Procedure & $\begin{array}{l}\text { Follow- } \\
\text { up, mo }\end{array}$ & Outcome \\
\hline 13 & 11 & HLHS & $\begin{array}{l}\text { One lung } \\
\text { EC-Fontan }\end{array}$ & $\mathrm{N} / \mathrm{N}$ & No & No & $\begin{array}{l}\text { One lung } \\
\text { EC-Fontan, } \\
\text { InV turndown }\end{array}$ & 15 & Alive, doing well \\
\hline 14 & 4.9 & $\begin{array}{l}\text { Heterotaxy, } \\
\text { unbalanced } \\
\text { AVSD, } \\
\text { interrupted } \\
\text { IVC, } \\
\text { bilateral } \\
\text { SVC }\end{array}$ & $\begin{array}{l}\text { Bilateral Glenn } \\
\text { (Kawashima). } \\
\text { Had ventricular } \\
\text { dysfunction, } \\
\text { heart failure, } \\
\text { cyanosis-high } \\
\text { risk for Fontan }\end{array}$ & $\mathrm{N} / \mathrm{N}$ & $\mathrm{N}$ & $\mathrm{N}$ & $\begin{array}{l}\text { Nonfenestrated } \\
\text { EC-Fontan } \\
\text { with LSVC } \\
\text { to LA } \\
\text { connection }\end{array}$ & 23 & Alive, doing well \\
\hline
\end{tabular}

InV, Innominate vein; $P L E$, protein-losing enteropathy; $P B$, plastic bronchitis; $S V$, single ventricle; $u$-CAVC, unbalanced complete atrioventricular canal defect; $E C$-Fontan, extracardiac Fontan; $A V$, atrioventricular; $Y$, yes; $N$, no; $R$, right; $A V V R$, atrioventricular valve repair; $R J S C$-RA, right jugular-subclavian junction to right atrium; $P A I V S$, pulmonary atresia with intact ventricular septum; $P A$, pulmonary artery; $H L H S$, hypoplastic left heart syndrome; $D I L V$, double-inlet left ventricle; $c / b$, caused by; $A V S D$, atrioventricular septal defect; $I V C$, inferior vena cava; $S V C$, superior vena cava; $L S V C$, left superior vena cava; $L A$, left atrium.

and divide (upstream InV can be controlled with vascular clip) and oversew the clamped segment; and (7) determine whether there is adequate length of the $\mathrm{InV}$ for primary turn-down or if an interposition graft is necessary. If length and atrial mobility permit, the appendage is partially amputated, and the pectinate muscles are resected to create an unobstructed inflow to the common atrium (Figure 3). The anterior aspect of the anastomosis may be enlarged by a pericardial patch. If length is inadequate, then use a ringreinforced (size based on size of patient) polytetrafluoroethylene interposition graft, standard anastomosis to the $\mathrm{InV}$, and then create an appropriate opening in the atrium and insert the graft to a depth of approximately 3 to 4 rings, securing it with a purse string and tacking sutures in essence a dunk technique (Figure 4). We have learned that not all appendages are easily mobilized; tangential clamping of thick atrial tissue with a beating heart can be imprudent. If an interposition graft is needed, we think the dunk technique eliminates most of the technical concerns and could potentially be done without cardiopulmonary bypass. ${ }^{2}$ If a right TD needs to be decompressed, an interposition graft is used from the internal jugular and subclavian vein confluence to the common atrium and a more complex reconstruction of venous system is required (C. Kreutzer, personal communication, 2020).

A final but important issue is the degree to which the jugular vein should be banded (above TD entrance) to balance right to left shunt. We individualize this as well, based on the degree of desaturation in the unbanded state. If during 2 to 3 postoperative days desaturation below $80 \%$ persists, while cardiac output is well preserved, the left jugular vein is approached through a short incision on the neck and is either banded ${ }^{2,19}$ or completely ligated if necessary. Before ligation, patency of collateral venous drainage via plexus basilaris and sinus cavernous should be confirmed in a catheter laboratory by balloon-occluding the left internal jugular vein and injecting contrast upstream.
Since January 2017, 14 patients with failing Fontan have undergone the $\mathrm{InV}$ turn-down procedure (Table 1) at Austral University Hospitals, Buenos Aires, Argentina (patients 1-6), and Children's Wisconsin, Herma Heart Institute (patients 7-14). The procedure was indicated as the last resort therapy in critically ill patients.

\section{THE NEED FOR A MULTIDISCIPLINARY APPROACH-FUTURE DEVELOPMENT}

Although new imaging techniques have shed light on the etiology and pathophysiology of lymphatic complications such as PLE, PB, and chylothorax, many questions remain. More research is needed into understanding the genetic and anatomic susceptibility in patients with single-ventricle physiology and lymphatic failure. In contrast to cardiovascular disease, which has been extensively studied, leading to the development of many interventional and medical therapy options, the lymphatic system is in its infancy, and there are currently no known lymphatic targeted medical treatments.

With the development of new TD-decompression procedures, it is becoming clearer that TD occlusion seems highly inadvisable. However, there is clearly value to perform SLDE of the tributaries documented to be the source of leak, as this will enhance the efficacy of therapeutic decompression, as pressure in a leak basin may be (likely is) lower than that in the atrium-so decompression alone may not stop the leak. ${ }^{20}$

The InV turn-down procedure is designed to target impaired lymphatic drainage in Fontan circulation. Contrary to the fenestrated Fontan circulation, in which the TD is drained into the high-pressure Fontan circulation, turn-down of the InV to the common atrium effectively decompresses the TD to the lower-pressure system with "diastolic suctioning" of lymph. At the same time, the preload of the single ventricle is increased at the expense 


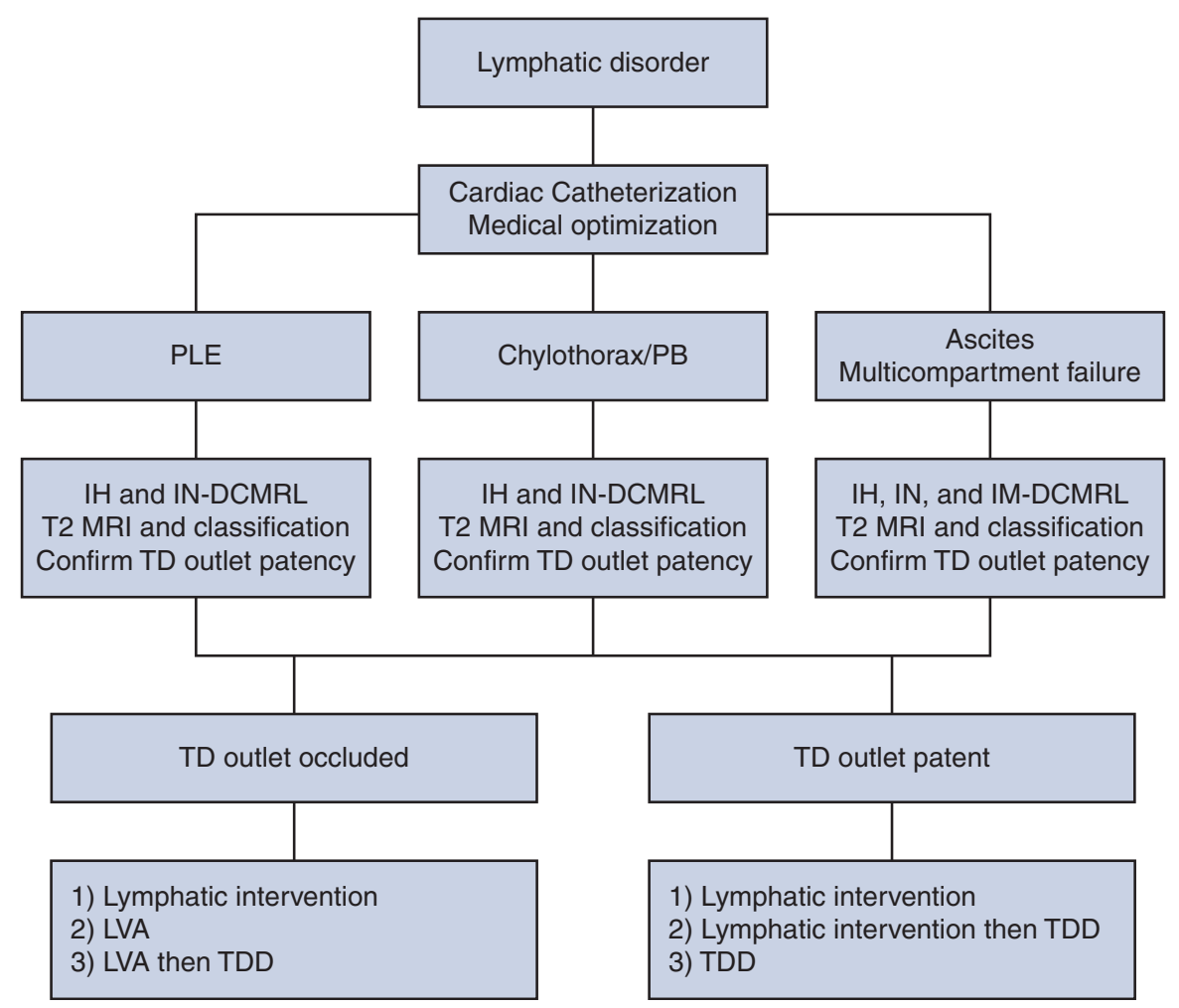

FIGURE 5. Decision-making tree. $P L E$, Protein-losing enteropathy; $P B$, plastic bronchitis; $I H$, intrahepatic; $I N$, intranodal; $D C M R L$, dynamic contrast magnetic resonance lymphangiography; $T 2 M R I$, T2 magnetic resonance imaging; $T D$, thoracic duct; $I M$, intramesenteric; $L V A$, lymphovenous anastomosis, $T D D$, thoracic duct decompression (innominate vein turn-down).

of the right-to-left shunt, which works as a fenestration, with subsequent acceptable desaturation. This connection offers an entrance for catheterization or electrophysiologic studies. An expected disadvantage is the gradual desaturation owing to the development of venovenous collaterals, which might be controlled by catheter intervention.
InV turn-down may be considered for medical and interventional-refractory post-Fontan lymphatic complications of persistent chylothorax, $\mathrm{PB}$, and protein-losing enteropathy (Figure 5). If TD outlet or InV are occluded and intervention fails to establish patency, one should consider creating a lymphovenous anastomosis to collateral vein (Figure 6) (V. Hraska, personal communication, 2020).
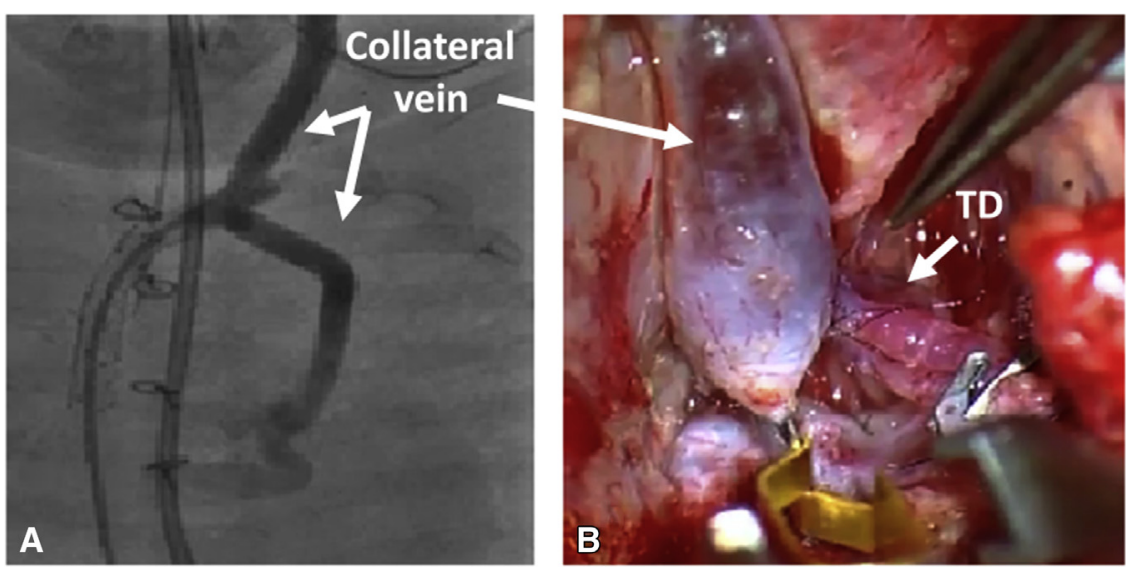

FIGURE 6. A, Complete occlusion of innominate vein in a patient with persistent, life-threatening chylothorax after arterial switch operation. Venous drainage is provided via the collateral vein (arrows). B, Thoracic duct is anastomosed with collateral vein (arrow). Notice the competent TD valve, which prevents venous blood from entering the TD. TD, Thoracic duct. 
Prophylactic InV turn-down may also be considered at time of the Fontan operation for patients with thoracic lymphangiectasia type 3 or 4 pattern at pre-Fontan MRI lymphangiography. ${ }^{9}$ Further studies are needed to determine the appropriate indication for this procedure.

\section{Conflict of Interest Statement}

The authors reported no conflicts of interest.

The Journal policy requires editors and reviewers to disclose conflicts of interest and to decline handling or reviewing manuscripts for which they may have a conflict of interest. The editors and reviewers of this article have no conflicts of interest.

\section{References}

1. Rychik R, Atz AM, Celermajer DS, Deal BJ, Gatzoulis MA, Gewillig MH, et al. Evaluation and management of the child and adult with Fontan circulation: a scientific statement from the American Heart Association. Circulation. 2019;139: e1-51.

2. Hraska V, Mitchell ME, Woods RK, Hoffman GM, Kindel SJ, Ginde S. Innominate vein turn-down procedure for failing Fontan circulation. Semin Thorac Cardiovasc Surg Pediatr Card Surg Ann. 2020;23:34-40.

3. Kreutzer C, Kreutzer G. The lymphatic system: the Achilles heel of the FontanKreutzer circulation. World J Pediatr Congenit Heart Surg. 2017;8:613-23.

4. Gosh RM, Dori Y. Prevalence and cause of early Fontan complications: does the lymphatic circulation play a role? J Am Heart Assoc. 2020;9:e015318.

5. Dori Y, Keller MS, Rychik J, Itkin M. Successful treatment of plastic bronchitis by selective lymphatic embolization in a Fontan patient. Pediatrics. 2014;134:e590-5.

6. Dori Y, Keller MS, Rome JJ, Gillepsie MJ, Glatz AC, Dodds K, et al. Percutaneous lymphatic embolization of abnormal pulmonary lymphatic flow as treatment of plastic bronchitis in patients with congenital heart disease. Circulation. 2016;22:1160-70.

7. Hraska V. Decompression of thoracic duct: new approach for the treatment of failing Fontan. Ann Thorac Surg. 2013;96:709-11.

8. Smith CL, Hoffman TM, Dori Y, Rome JJ. Decompression of the thoracic duct: a novel transcatheter approach. Catheter Cardiovasc Interv. 2020;95:E56-61.

9. Kreutzer C. Lymphatic decompression concomitant with Fontan/Kreutzer procedure: early experience. World J Pediatr Congenit Heart Surg. 2020;11:284-92.
10. Boedtkjer DB, Rumessen J, Baandrup U, Skov Mikkelsen M, Telinius N, Pilegaard $\mathrm{H}$, et al. Identification of interstitial Cajal-like cells in the human thoracic duct. Cells Tissues Organs. 2013;197:145-58.

11. Mohanakumar S, Majgaard J, Telinius N, Katballe N, Pahle E, Hjortdal V, et al. Spontaneous and a-adrenoreceptor-induced contractility in human collecting lymphatic vessels require chloride. Am J Physiol Heart Circ Physiol. 2018; 315:H389-401.

12. James H, Witte MH, Bernas M, Barber B. Proposal for prevention or alleviation of protein/lymph-losing enteropathy (PLE/LLE) after Fontan circulation treatment of univentricular hearts: Restoration of lymph balance with a "lymphatic right-to-left shunt." Lymphology. 2016;49:114-27.

13. Brace RA, Valenzuela GJ. Effects of outflow pressure and vascular volume loading on thoracic duct lymph flow in adult sheep. Am J Physiol. 1990;258: R240-4.

14. Biko DM, DeWitt AG, Pinto EM, Morrison ME, Johnstone JA, Griffis H, et al. MRI evaluation of lymphatic abnormalities in the neck and thorax after Fontan surgery: relationship with outcome. Radiology. 2019;291:774-80.

15. Biko DM, Smith CL, Otero HJ, Saul D, White AM, DeWitt A, et al. Intrahepatic dynamic contrast MR lymphangiography: initial experience with a new technique for the assessment of liver lymphatics. Eur Radiol. 2019; 29:5190-6

16. Mohanakumar S, Telinius N, Kelly B, Lauridsen H, Boedtkjer D, Pedersen M, et al. Morphology and function of the lymphatic vasculature in patients with a Fontan circulation. Circ Cardiovasc Imaging. 2019;12:e008074.

17. Dori Y, Smith CL, DeWitt AG, Srinivasan A, Krishnamurthy G, Escobar FA, et al. Intramesenteric dynamic contrast pediatric MR lymphangiography: initial experience and comparison with intranodal and intrahepatic MR lymphangiography. Eur Radiol. 2020;30:5777-84.

18. Mejia E, Otero H, Smith C, Shipman M, Liu M, Pinto E, et al. Use of contrastenhanced ultrasound to determine thoracic duct patency. J Vasc Interv Radiol. 2020;31:1670-4.

19. Bauer C, Mair R, Mair R, Tulzer G. Thoracic duct decompression and jugular vein banding — an effective treatment option for protein-losing enteropathy and plastic bronchitis in severe failing Fontan circulation: a case report. Eur Heart J Case Rep. 2020;4:1-4.

20. Woods RK, Hraska V. Commentary: Lymphatic fluid flows uphill in both hemispheres_and leaks in the same places. J Thorac Cardiovasc Surg. August 15, 2020 [Epub ahead of print].

Key Words: failing Fontan, chylothorax, protein-losing enteropathy, plastic bronchitis, thoracic duct, lymphatic circulation 